\title{
CARL DIEM - A SIGNIFICANT SPORTS PERSONALITY FOR GERMANY, EUROPE, AND BULGARIA ATTEMPT AT ANALYSIS AND ASSESSMENT
}

\author{
Jörg Schenk
}

\section{OPEN ACCESS}

Submitted: 6 July 2021 Revised: 14 October 2021 Accepted: 30 November 2021

ORCID iD

Jörg Schenk https://orcid.org/0000-0002-9882-3739 Cite this article as: Schenk, J. (2021)

Carl diem - a significant sports personality for germany, europe, and bulgaria Journal of Applied Sports Sciences, Vol.2, DOI: $10.37393 / J A S S .2021 .02 .8$

$$
\begin{array}{r}
\text { COC } \\
\text { This work is licensed under } \\
\text { a Attribution-Non } \\
\text { Commercial-ShareAlike 4.0 } \\
\text { International (CC BY-NC-SA 4.0) }
\end{array}
$$

National Sports Academy "Vassil Levski", Sofia, Bulgaria

\section{ABSTRACT}

The German Carl Diem is considered one of the most outstanding sports personalities and Olympic promoters of modern times and was not only relevant to sports development in and for Germany but also abroad. His work unfolded especially in the first half of the 20th century but led to highly contradictory assessments of his person and his work due to the circumstances of the time and political developments in Germany and Europe. It becomes apparent that in contrast to Germany, where Diem is now almost forgotten despite an almost incalculable oeuvre and is only known to sports historians, in Bulgaria, where he created the essential basis for the establishment and structure of the "State Higher School for Physical Education”, later "National Sports Academy 'Vasil Levski",, and thus the academic training of sports teachers with his "Organizational Plan for Physical Education in Bulgaria”, there was initially no mention of him after 1944 and only from the 1990s of the last century at least some few mentions. This article uses an overview of the academic literature to shed light on Diem's changed reception in Germany as well as the deficient research situation on him in Bulgaria.

Keywords: Carl Diem, Organizational plan, Higher School of Physical Education, Bulgaria, Olympia

\section{SUMMARY OF RESEARCH \\ PROBLEM}

The XI Olympic Games (Berlin 1936) and the Olympic Winter Games in Garmisch-Partenkirchen in the same year marked a special moment in the history of sports in the 20 th century. Their organization per se, as well as their dimensions in terms of the participating nations, the number of new Olympic and world records, the sports facilities, and their media impact, etc., on the one hand, as well as the instrumentalization of the Olympic Games as an element of party-political propaganda aimed at the exhortation of the all-powerful system in Germany, on the other, assumed unprecedented proportions.

The conception and organization of the
1936 Olympic Games were the work of Carl Diem (1882-1962). Carl Diem was a prominent sportsman, educator, sports researcher, manager, official, and journalist of international importance. For political reasons, he was officially only second-in-charge as the "Secretary-General", after Theodor Lewald, the Chairman of the Organizing Committee (OC) and former Chairman of the German Imperial Commission for Physical Education (Deutscher Reichsausschuss für Leibesübungen).

Along with his undisputed qualities as a sports manager, Carl Diem is considered the most significant supporter of the Olympic idea and the Olympic Games. He was a follower of Pierre de Coubertin, making him a natural authority in the preparation and organizing of 
the 1936 Olympic Games in Berlin and the IV Winter Olympic Games in Garmisch-Partenkirchen. Undoubtedly, something which is inevitably associated with Carl Diem but not sufficiently known is the introduction of one of the most important ceremonies in the Olympic Movement. Until 1936, the Olympic flame was lit at the stadium during the official opening of the Games. Inspired by several ideas which are still disputed even today, Carl Diem developed a program to carry the Olympic flame from Olympia, the ancient capital of the Olympic Games, to the current capital of the Olympic Games - in this case, to Berlin for the first time in 1936, as a "torch run". This largescale international sporting event which even today is regarded as a canonical element of the Olympic Movement was carried out at the order of Joseph Goebbels together with Theodor Lewald. $^{1}$

If until 1936, Carl Diem was an unconditional sports personality and organizer who laid the foundations for the entire system of the sports movement in Germany based on mass involvement of the population in systematic physical activities through development of communal based structures of sport organizations and the building of public state sports facilities through the organizational unification of sports clubs and societies, the huge impact of the Olympic Games in Berlin as a manifestation of the Olympic sports culture brought Carl Diem to international prominence.

After the 1930s, through his involvement with the Olympic Movement, although not a member of the $\mathrm{IOC}^{2}$, his views and achievements in organizing the sports movement became extremely popular, above all abroad. For example, he was responsible for a comprehensive reform of sport in Turkey and also assisted other European governments in building modern educational and organizational structures in the field of sport. ${ }^{3}$ Bulgaria also belongs to the countries where his contribution to reforming the system of physical education and sport, one of which, for example, is of great importance today, was the establishment in 1942 of the National Sports Academy, then the Higher School of Physical Education.

In Germany itself, Carl Diem left his mark

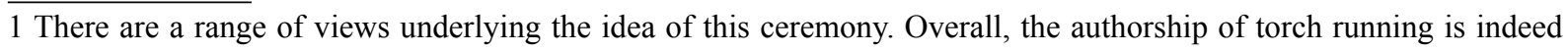
attributed to Carl Diem. For now at least, and according to the overwhelming majority of academics, this is in fact probably based on an idea and initiative of archaeologist Alfred Schiff, administrative director of the Berlin German University of Physical Education, founded in 1920 in Berlin. See also Lehmann, S. (2008). (invoked on 14.08.2020). Hristova, D. (2012). She raised the question of Bulgarian authorship, but apart from rather weak assumptions by academics and the fragmented memories of individual witnesses of the time, she failed to provide convincing evidence that the idea of the torch run was born in Bulgaria.

2 Diem's enthusiasm and commitment to sport was not only of a purely idealistic nature: even as a young man, he had written on sporting topics for various newspapers and publications for a fee, thus financing his livelihood and various trips to major sporting events. This resulted in competence and publicity, which brought him to full-time positions professionally, e.g. Secretary General of the German Imperial Commission for Physical Exercise („Deutscher Reichsausschuss für Leibesübungen“, a kind of umbrella organisation for sports in Germany; abbr. DRA, DRL or more rarely DRAfL), Vice-Rector of the German Higher School for Physical Exercise or Secretary General of the Organising Committee of the Olympic Games in Berlin. This led the IOC to consider him a ,professional“ and not to let him become a member. Cf. Krüger, M. (2012), pp. 204.

3 In the 1930s in particular, Carl Diem undertook numerous, partial repeat visits for researching the models and systems of organization of sport and physical education not only to the US and Japan, but also other European countries, including Great Britain, Belgium, Italy, Austria, Switzerland, Norway, Sweden, Finland, Hungary, Greece, Turkey and Bulgaria. See also CuLDA (n.y.). Gesamtverzeichnis Tagebücher Carl Diem. 
on German sports and, in particular, Olympic sports for more than six decades within the framework of four German systems of government:

- during the German Empire

o Imperial period, 1905-1918

o ‘Weimar Republic', 1919-1933

○ 'Third Reich' (National Socialism), 1933-1945

- and after the Second World War during the Federal Republic of Germany since 1949 until his death in 1962.

It is here that he enjoyed great recognition for his achievements in the field of sport organization for example the attempts at unification of the two most important physical culture organizations in Germany at that time. ${ }^{4} \mathrm{He}$ also launched the so-called youth competitions of the Reichsjugendkämpfe (later in the Federal Republic of Germany Bundesjugendspiele, „Federal Youth Games”), the introduction of the German Sports Badge ${ }^{5}$, which even served as a prototype for the establishment in the Soviet Union, and hence all its satellites (in Bulgaria in 1948) of the fitness program "Prepared for Work and Defence". (Commission on Dossiers - COMDOS (Ed.) (2014), Mitev, (1996a). He was also instrumental in the establishment of the German Higher School of Physical Education (DHfL) in 1917-19, the organization of the Games of the XI Olympic Games (Berlin 1936), as well as the first Olympic Torch Run, inter- national consultancy activity, was one of the promoters of the reconstruction of the ancient stadium in Olympia/Greece and founder of the International Olympic Academy in 1961, etc.

His activity and his personality, however, have been the subject of serious analysis and totally different and radical assessments affecting not so much his activity as a persona but his political behavior. For more than 60 years, therefore, the research and discussions of his activities and contributions in Germany have led to political and ideological disputes, which in one way or another influence not only the objective assessment of his life. These circumstances still form different attitudes and assessments towards his activity as a sports leader and functionary. Indeed, there is also a tendency for the specific indisputable contributions that he left as a legacy to the sports movement to this day to be concealed or downplayed for various political reasons.

\section{AIMS AND OBJECTIVES OF THE RESEARCH}

In Germany, Carl Diem has been perceived not only positively, but also critically, even inimically, by his contemporaries and subsequent generations. This is determined by his extraordinarily ambivalent political behavior (or lack thereof) in the conditions of the Nazi regime in Germany. This ultimately makes him, as well as his political life and work so

\footnotetext{
4 The attempts to unite gymnastics and sports movements at the beginning of the 20th century, the German Gymnastics Association, which drew on F.L. Jahn and cultivated civic-national ideals, on the one hand, and the German Imperial Committee for Olympic Games, which emphasised the idea of competition and performance, on the other, was ultimately short-lived and ended as early as 1923/24 with the „Clean divorce“, the separation of modern sports on the one hand and gymnastics on the other. Cf. Krüger, M. (2009) and Stępiński, M. (2015).

5 During the Olympic Games in Stockholm in 1912, Diem became familiar with the sports badge awarded in Sweden („Idrotts-Märket“, 1907) and incorporated this into his sports badge initiative. This badge has undergone several renamings over the decades. In Germany nowadays the "German Sports Badge" ("Deutsches Sportabzeichen") is awarded.
} 
controversial and vulnerable, not only in life but especially after his death. ${ }^{6}$

The present study does not focus on the search for biographical discoveries and participation in this discussion. ${ }^{7}$ However, a detailed study of his activities in Bulgaria is aimed at the objective presentation. It also aims to provide an overview of the contemporary situation regarding literature and research relating to Carl Diem in Germany and abroad, which would give wider opportunities for assessment of the significance and impact of his work in Bulgaria.

\section{ORGANIZATION AND METHODOL- OGY OF THE STUDY}

This study covers several main areas of information gathering. First of all - studies of documents and information related to the life and activities of Carl Diem in Germany and Europe, including Bulgaria. Secondly, it requires a very thorough review of the existing research of historical, political, biographical, sports, political and organizational nature, related to the presentation and evaluation of Carl Diem's activity as a sports activist and manager.

The particular contribution of this research is that it covers studies by authors from Germany, Europe, and Bulgaria. This necessi- tated research into documents from the Carl \& Liselott Diem Archive (CuLDA) at the German Sport University Cologne (GSU Cologne) / (Deutsche Sporthochschule Köln (DSHS Köln), a number of libraries in Germany, as well as specialized literature in the Historical Archives of the NSA, the National Library "St. Cyril and Methodius", State Archives - Sofia, etc.

In methodological terms, the documentary information and systematic information collated from scientific and popular publications were examined on the basis of the so-called "content analysis", critical and comparative analysis.

Analysis and evaluation of Carl Diem in literary sources

\section{REVIEW OF STUDIES IN GERMANY}

There are countless literary sources and research about Carl Diem, as well as his own written legacy, especially in the German language.

Diem himself left behind him an extremely extensive collection of written work kept in the archive „Carl und Liselott Diem-Archiv” (CuLDA), formerly „Carl Diem Institut” at DSHS Köln, founded in 1964 by the German National Olympic Committee as an Olympic Institute.

This legacy encompasses a huge number

6 Jungbauer, A. (2004). „In addition to his publications „Sturmlauf durch Frankreich“, 1941, and „Olympische Flamme“, his speech of 18 March 1945 was very often addressed: „Before the members of Hitlerjugend and of Volkssturm in the Dome Hall of the Berlin Olympic Complex, Carl Diem made the so-called "Speech for Sparta" and called for a , final sacrifice in the name of the Fuhrer'. While Soviet artillery fire could already be heard in the capital, Diem compared the youth of the National Socialist state to the militarized youth of Sparta and quoted the ancient Greek poet Tyrteus with the words ; It is a beautiful death when the noble warrior fights for the fatherland, dies for the fatherland '. In the days following the address, which historian Frank Becker decades later would describe as an „encouraging speech“, hundreds of young men died in the battle for Berlin trying to use hand firearms and anti-tank hand grenade launchers to deter the tank units of the advancing Soviet troops.", (invoked on 22.12.2020) Cf. Krüger, M. (2012); Benz,W. (2011). Laude, A., Bausch, W. (2000).

7 This publication is part of a monograph on the work of Carl Diem in Bulgaria in the 1930s and 1940s. 
of publications, speeches, reports, journals (ca. 12,000 pages), letters and correspondence (ca. 50,000 separate letters), as well as specific files in relation to his various activities as a functionary, photo albums, testimonies, and other written materials.

The primary authors who have studied the life and work of Carl Diem are Michael Krüger, Frank Becker, Karl Lennartz, Horst Ueberhorst, Wolfgang Benz, Jürgen Buschmann, Achim Laude, Ralf Schäfer and others. It can be assumed on the basis of the general concepts that:

In his lifetime, Carl Diem was considered a man who despite his national-conservative thinking was politically very adaptable, and in his professional sphere of sports, was considered an innovative and creative sports leader.

In order to get a better idea of the person of Carl Diem, it would be appropriate, first of all, to focus on three aspects: Diem as a politician and state leader in the field of sport, distinguished by great adaptability and flexibility to those in authority and with responsibility for political decisions; secondly, as a sports ideologist committed to his views on sport and to his doctrine and finally as an innovator and creator of organization and management of the sports movement. Thus, was he able to create the foundations of the state and social model of physical education and sports systems, still relevant to this day. They continue to have an impact on what Spyros Kapralos, the President of the EOC, defined as the European model of sport in terms of the academic and organizational aspects of modern sport. (Kapralos, 2019, European Parliament, 2012)

Diem acquired an important place in science due to his wide range of written works on sports history and theory. One of the most significant of these was "World History of Sport", but most of his works were accomplished during and after completing his mandate as the Vice-Rector of the German University of Physical Education (Berlin, 1920-1933) and later as Rector of the German Sports University founded in Cologne in $1947 .{ }^{8}$

Some of them are to be found in the following monographs, which subsequently rank among his more significant works:

- Olympische Flamme. Das Buch vom Sport, 3 volumes, $1942^{9}$

- Asiatische Reiterspiele. Ein Beitrag zur Kulturgeschichte der Völker, 1941

- Körpererziehung bei Goethe. Ein Quellenwerk zur Geschichte des Sports, 1948

- Lord Byron als Sportsmann, 1950

- Weltgeschichte des Sports, 1961

- Ein Leben für den Sport. Autobiographie, editiert aus dem Nachlass von Carl Diem, (1974)

In 1967, under the title "Carl Diem - Der olympische Gedanke" (Published by Carl Diem Institut, 1967), a collection of speeches and writings was published to define the

\footnotetext{
8 Diem himself had neither studied nor defended a doctoral thesis, and muchless was a qualified professor. His appointment as Vice-Rector became possible after Theodor Lewald managed to appoint sports-loving medical doctor Prof. Dr. August Bier to the position of rector of that newly established Higher School, who in turn expressed his gratitude by awarding in 1921 Carl Diem, his deputy, the title „Dr. med. h.c.“ of the University of Berlin. In 1932, Ferdinand Sauerbruch, another world-renowned surgeon, succeeded Bier as rector. Under pressure from the "Reichssportführer" Hans von Tschammer und Osten, Diem resigned from his position as prorector at the beginning of May 1933.

9 This work is considered one of the most important testimonies of the time of National Socialist propaganda in the field of sports.
} 
essence of the Olympic idea and principles, fundamental to the further development and explanation of Coubertin's ideas.

However, this is not an exhaustive review of the literature about Carl Diem. While Diem was still alive, an extensive, and initially largely positive commentary and analysis of his work was begun. This changed in the early $1950 \mathrm{~s}$, when his pre-war activities, particularly those in the field of politics, began to be increasingly critically questioned. However, particularly in the last 30 years or so and especially in the field of sports history, there have been a large number of academic developments, studies, works, and other publications in which Carl Diem has been mentioned predominantly critically. Today, after Diem's death this type of reception is garnering an increasing number of supporters and has a much broader public impact. ${ }^{10}$ As a result, many cities in Germany have seen streets, squares, schools, and sports facilities renamed. ${ }^{11}$

The conflict concerning the correct interpretation of his activities and their implications for the development of sport, in general, became particularly clear in the writings of Diem's critics and other renowned academics on the occasion of the Congress of the German Sport Uni- versity Cologne on 10 and 11 December 2010 on the theme "Culture of Memory in Sport". ${ }^{2}$

The so-called "Debate on Diem" was in general terms focused primarily on Diem's political behavior, his inclination towards subordination, and his ability to deal with those in power, particularly during the period of $\mathrm{Na}$ tional Socialism. It is from this point of view that the organizational aspects of his activities were also highlighted.

Today in the historical analysis of the life and work of Diem, the biography entitled „Den Sport gestalten. Carl Diems Leben (1882-1962)" by Frank Becker, originally published in four volumes, but the most recent edition of 2019 published in a single volume, is valid in that it sets out the direction for analysis of his life work, but it is by no means the "only correct", or indisputable version. ${ }^{13}$ It was commissioned by the German Olympic Sports Federation which challenged it at first. Due to its exceptional detail, this biography has also been used in this article as one of several essential sources of reference. Other well-known critics of Diem include, for example, Ralf Schäfer, Wolfgang Benz ${ }^{14}$, Achim Laude, and Wolfgang Bausch, who question whether Diem is suitable to serve as an example

10 Cf. Lohde, E. (2013). The author herein describes four phases of the debate after 1950. However, the aforementioned "Debate on Diem" is not the subject of this review.

11 The German Sport University Cologne lost a lawsuit that was filed due to the renaming of its street from Carl-DiemWeg to Am Sportplatz Müngersdorf.

12 Mentel, Ch. (2012). „Prof. Dr. Frank Becker has been teaching newer and newer history at Duisburg University since 2011. Since 2005, he has been working on the three-year research project „The Life and Work of Carl Diem” [...], awarded by public competition from the German Sports Federation, respectively. The German Olympic Sports Federation and the German Sport university Cologne, whose founding director was Diem. [...] After the completion of the project and during the publication phase, an open conflict ensued between Becker and several representatives of the Academic Council with regard to the research project, [...] which in their final project report [qualified] Becker's work as academically unsatisfactory.“ (invoked on 08.02.2021).

13 „Based on a public evaluation published on 1 February 2012 by the German Olympic Sports Federation, Becker“s recommendation with regard to the memory of Diem became a guide to its own position in the Debate on Diem. "Text of the publishing house to the third edition of „Den Sport gestalten“ (2019) Duisburg.

14 Benz, W (Edit.) (2011). Until 2011 W. Benz had for many years been director of the „Centre for the Study of AntiSemitism“ at Berlin University. In 2020, not for the first time, as a result of a number of speeches he had made, found himself the focus of criticism of anti-Semitism, accusing him of ,belittling anti-Semitism“. 
or worthy to be remembered. For example, they accuse him of subconscious anti-Semitism, even open manifestation of such, as well as of a largely uncritical attitude towards the ruling systems, in particular National Socialism. This cumulates last but not least in his "Speech on Sparta" at the end of the war, which, in their opinion, calls his essential activities into question and justifies criticism of them. ${ }^{15}$

In opposition to this group of so-called "critical historians" there is another group which they and their supporters somewhat disparagingly refer to as the group of "Diemologists" or "apologists of Diem". Renowned scholars such as Michael Krüger, chairman of the Scientific Council, Karl Lennartz, former lecturer at the German Sport University and long-time head of the CuLDA, or Ommo Grupe, founder of modern sports pedagogy and sports science based on philosophical anthropology advocate a more positive point of view to Diem's work reproaching their opponents for their scientific errors. (Krüger, (Edit.) (2012); id. (2010))

The true achievements of Carl Diem, the unification of gymnastics and sport, the imposition of a positive understanding of sport, the promotion of the Olympic idea, modern achievements in the field of organization and politics of sport, and last but not least his contribution to the history of sport, however, are almost unquestioned by critics. Perhaps it is these undeniable successes and achievements, that are the reason why, from a modern perspective, his political behavior seems so much more questionable and deserving of criticism.

In conclusion, it should be emphasized that both sides in the discussion acknowledge the importance of the contributions of Carl Diem have not only national but also international significance. The differences in positions relate to the extent of this recognition and the details of knowledge about him and his assessment.

In this sense, there is undoubtedly academic consensus that the achievements and contributions of Carl Diem are of great importance for the development of the sports movement in Germany and Europe, as well as his undeniable contribution to the development of the Olympic movement. It is no coincidence that in 1956 he was awarded the most prestigious award of the IOC, the Olympic Diploma of Merit, for his special contribution to the Olympic Movement. ${ }^{16}$

The second important issue concerning the clarification of Carl Diem's activities in Bulgaria remains unstudied by German historians. In this sense, this warrants in-depth research in this regard in the aims of enriching the existing research literature.

\section{Bulgaria}

In this context, there seem to be relative sparse academic works on Carl Diem in Bul-

15 Carl Diem's ideas and behaviour bear the clear imprint of national conservatism. Although he was not a supporter of the National Socialists and was even under suspicion by them because of his marriage to the "quarter Jew" (a slang term of the time) Liselott Diem, maiden name Bail, as well as his "friendship with Jews", the ambitious and opportunistically adaptable Diem managed to adjust to the conditions of the Third Reich. Proof of this is his appointment in 1939 as Reichssportführer Gau Ausland (Reichssportführer of the Region (Gau) Abroad) - an official post in the National Socialist power apparatus.

16 This award, founded in 1905 by Pierre de Coubertin for exceptional contributions to sports and the Olympic ideals, was granted a total of 57 times between 1908 and 1974. Since 1975 in accordance with its award statutes the IOC instead recognises outstanding services to the Olympic Games with the "Olympic Order". 
garia. In Bulgarian sports historiography of the 1960 s and $1970 \mathrm{~s}$, he is mentioned as one of the advocates of bourgeois sports ideology against which socialist sport was engaged in an ideological struggle. He was mentioned in the works of Vasil Tsonkov, Nikola Popov, Natalia Petrova, and Angel Stoychev. In recent times, after the political changes in Bulgaria, the activities of Carl Diem have been presented in a very limited scope in the research work of Rayna Bardareva with regards to the establishment of the National Sports Academy. Lozan Mitev in his dissertation examined the activities of Carl Diem as the first propagandist of the Olympic idea in Bulgaria and as a reformer of sport in Bulgaria. (Mitev, 2002)

The reason for this may be multi-layered. Indeed, Diem visited Bulgaria on a number of occasions, according to reliable reports in 1933, 1937, 1939, 1940, 1942, as well as passing through in 1943 and 1944 on his way to Turkey. ${ }^{17}$ However, his activity acquired importance and necessity of a complex reform of the educational system in the field of sport. This took place during the war and therefore under restrictive conditions and against the backdrop of the subsequent total change in the dominant public order.

What were the reasons for Diem's visits to Bulgaria? As Bulgaria grew politically, economically, and culturally closer to the German Reich after the mid-1930s, and especially after the 1936 XI Olympic Games, German sport as a whole, but also the way in which it was organized, in particular training, became increasing- ly the focus of the attention of those responsible for political decisions in Bulgaria. (Zlatarski, 20202, Hoppe, 1979, Stein, 2011). Tsar Boris III himself, from the beginning of July to the beginning of September 1936, embarked on a long journey through Europe, which, like his earlier journey in 1934, took him back to Berlin, this time to these very Olympic Games. Whether or not he met Carl Diem there, is unclear. In any case, the Bulgarian team did not perform very successfully at these games, resulting in attention being focused on a radical reform of physical education and sport. (Mitev, 2014, pp. 70; Hoppe, ibd., pp. 47)

Thus, advice and support were requested from the German government, which complied with this request by giving Diem's employer, Reichssportführer Hans von Tschammer und Osten, leave of absence to carry out this task and send Diem to Bulgaria. (CuLDA: Carl Diem Tagebücher. pp. 1344). He arrived in Sofia in September 1937.

Carl Diem was already a recognized sports personality at the time of this visit to Sofia, which was to prove the most important one for Bulgarian sport. He had proven himself with his wide-ranging broad knowledge in the eyes of the German government and many foreign observers.

Another decisive element in the choice of Carl Diem as a government adviser was the fact that since 1932 he had worked closely with Stefan Chaprashikov, honorary chairman of the BOC and prominent member of the International Olympic Committee. ${ }^{18}$ Chaprashikov was at that time Bulgarian ambassador to Ber-

17 The visit by plane planned for November 1941 had to be cancelled due to the weather situation.

18 Stefan Chaprashikov, a wealthy Bulgarian industrialist and diplomat in Berlin, Vienna and Moscow, etc. and close to the Bulgarian royal court, in September 1929 in Lausanne during the 28th session of the IOC was elected as a member and held this post until his suicide in 1944. In 1936, he obtained from the German Reich through Philip F. Reemtsma a donation of 20,000 Reichsmarks, which allowed the Bulgarian athletes to take part in the Olympic Games in 1936. 
lin and had organized Carl Diem's 1933 visit to Sofia. It is important to note that Stefan Chaprashikov, although not well known in Bulgaria anymore, has been one of the most important figures of Bulgaria in the Olympic movement to this day. He was one of the four distinguished figures in the IOC, who were supporting the IOC president Count Henri de Baillet Latour.

Diem's concrete task was "to elaborate a general plan for physical education in schools and clubs" based on the "Law on the Physical Education of Bulgarian Youth" (ЗФВБМ - ZFVBM), which had been in force since 1931 , and the "to determine the application of this law in Bulgaria". The latter certainly led him to conclude that "the law is essentially not implemented."19

His students f rom the German Higher School of Physical Education included: Borislav Yordanov, Georgi Karaivanov, Mladen Filipov, and Krum Katsarov. All of these were to provide him with direct and permanent assistance in the preparation and organization of his mission.

Over a period of about two and a half months in the autumn of 1937 Diem developed an "Organisational Plan for Physical Education in Bulgaria". ${ }^{20}$ This work was published the same year in Sofia in the translation of M. Filipov and B. Yordanov, at that time inspectors at the Ministry of Public Education. (Uchilishten pregled, 1938). After this initial visit, Diem traveled to Sofia three more times (in 1939, 1940, and 1942). ${ }^{21}$ While in 1940 he wrote in his diary that his "plan $[\ldots]$ is still very far away" (CuLDA, 2009, pp. 1635), two years later he had already noted his conversation with Karaivanov on 23 March 1942:

"The Law on the Higher School [...] has been promulgated. Four-years term of study. Sports gymnastics as a main discipline, in addition to an academic discipline. Four professorial chairs: Medicine, Pedagogy and two practical departments, in addition to it extraordinary academic and practical training. By April all will be set out in the law. Karaivanov hopes to acquire a department and a directorship. Yordanov is excluded because he is married to a Jewish woman (owner of a manicure parlour)." (Ibd., pp. 1730)

The plan launched by Diem in November 1937 coincided with a phase of Bulgarian educational policy, in which there was university or tertiary training for future teachers with academic aspirations for the majority of school subjects, but not for gymnastics and physical education or its teaching staff. ${ }^{22}$

Diem wrote about this:

"The older gymnastics teachers are trained in courses of Yunak gymnastics association; some younger teachers have been abroad at various institutions. As a result, I was told that the gymnastics teachers trained at the Czech

19 The reasons for this are manifold. First and foremost, Bulgaria's deep economic, financial and social crisis, which lasted well into the 1930s, is partly responsible for the failure of the law.

20 Diem stayed in Bulgaria from 15.09. to 30.11.1937. He undertook a series of trips around the country, at the end of which in addition to the „Organizational Plan”, he published a long article in „Zora“ newspaper, gave a speech on the radio and a report at the Royal Cinema prior to the screening of Leni Riefenstahl's film about the Olympic Games in Berlin. See also Zlatarski, ibd., p. 323

21 The other two trips in 1943 and 1944 were merely transits without substantial encounters or talks.

22 Diem, who considered himself a „,sportsman“ throughout his life, makes no consistent or comprehensible distinction in his organisational plan between ,education in gymnastics“, ,education in sports“ and ,instruction within the framework of physical education". 
University in Prague were the very worst, only slightly better were the results at the Higher School of Physical Education in Warsaw, whereas they were satisfied with the fouryear training at the Royal Hungarian Higher School in Budapest. .... The education gained there is modern and thorough. The Bulgarians have entrusted leading positions only to teachers who were educated at the German College of Physical Education; these teachers hold the 4-6-month gymnastics teacher courses run by the Ministry of Education. Accordingly, the younger gymnastics teachers have a modern orientation and give brisk, natural gymnastics lessons. Here again, this is impaired by the community education at progymnasia, where the gymnastics lessons are mostly geared to the physically weak girls." (CuLDA, 2009)

This "Organizational Plan" was the first of its kind in Bulgaria, establishing state-oriented sports policy and governmental progress, where also was included and defined the framework for science-based, academic training of teachers of sports. It became crucial for the establishment and structure of the State Higher School of Physical Education in Sofia, the future National Sports Academy. ${ }^{23}$

In January 1944, immediately after the bombardment of Sofia, Diem last traveled through Bulgaria on his way back from Istanbul to Berlin, without however contacting the local sports officials.

After World War II, Diem's name was erased in the countries previously associated with the German Reich or in which Nazi-led politics had an impact and were now occupied by the Soviet Union. His work and publications were placed on the "black list" and thus consigned to oblivion or prohibition.

Thus, unlike before 1944, when his work and his visits to Bulgaria were largely reported on by the local press, there is evidence only of a very small number of publications related to Carl Diem in Bulgaria. The quality and quantity of references to Carl Diem himself and of his activities in Bulgaria in the form of written testimonies, notes, articles in the press, bilateral intergovernmental communication, etc. is relatively limited. ${ }^{24}$ Indeed, before the changes in 1989/90, the German official had been mentioned here and there in the academic sports literature, but only tangentially in the context of the general political situation, under the strong influence of ideology, and almost exclusively negatively. This was because he was perceived as a representative of a system "hostile" to the communist worldview.

After the end of the 1980s, Carl Diem once again came into the spotlight of Bulgarian academic research in the history of sport. Authors worthy of particular mention are: R. Bardareva, Lozan Mitev and in recent times E. Vitanova (Bardareva, 2002, Mitev, 1996b, Vitanova, 2016). However, there is still no evidence of a single publication explicitly dedicated, and much less exclusively, to the work of Carl Diem as a central theme. The academics mentioned above refer to Diem more "among oth-

\footnotetext{
23 Lozan Mitev (2002) was one of the first to mention Diem's plan in the newer Bulgarian scientific literature. In his dissertation he presented a number of aspects of its more significant aspects.

24 Nevertheless, throughout his life, Diem himself was very keen to collect evidence of his activities at home and abroad. In addition to the „Tagebücher” (diaries) cited here from the „Sachakten“ (subject files) of the CuLDA (folders 508 to 510), further evidence can be found in folders 806 and 81 1. A study of these as well as of the „organisational plan“ in particular is reserved for a further study.
} 
ers", and mainly in the context or in terms of other topics, e.g. the history of the National Higher Sports School, the Olympic Games in general, the International Olympic Academy, or the Olympic Movement in Bulgaria.

Moreover, his work in Bulgaria is not of a purely sports or pedagogical nature, but also pervaded by a political dimension, since the proposals for reform set out in his "Organizational Plan" of 1937 also sought to unify and involve all sports organizations along the lines of the prevalent German "Nationalsozialistischer Reichsbund für Leibesübungen" under the leadership of Reichssportführer Hans von Tschammer und Osten. This provoked a strong resistance from the independent Bulgarian sports organizations which had hitherto existed, such as The Bulgarian National Sports Federation (BNSF), which was subordinate to the Bulgarian youth organization "Brannik", comparable to the "Hitler Youth". In accordance with the political situation, Brannik was forced to unite into a common sports organization with the Union of Bulgarian Gymnastics Societies "Yunak" in order to enhance control by the state. In 1944, when the Communists came to power, this forced unification was dissolved. (Mitev, 1996b)

\section{CONCLUSION}

Notwithstanding the appearance of other sports officials at that time and given the general dynamic development of sports and the associated enthusiasm, Carl Diem had a particular importance for sport in Germany in the 20th century, above all in terms of:

- organization:

- training and methodology

- Olympic philosophy and education

- Sports politics and society

Furthermore, his international contribu- tions to the Olympic idea are undeniable. He saw himself as a friend of Pierre de Coubertin, whom he met for the first time in 1909 and then on many other occasions until 1937, as his follower and guardian of his Olympic ideals. (Lennartz, 2000). The XI Olympic Games in 1936 and their success, as well as his commitments to sport in the country and abroad in general and the Olympic movement in particular, put him on a par with Coubertin, Baillet-Latour, Edström, and Brundage.

Carl Diem is indisputably important for Bulgaria and Bulgarian sport. The fact that in Germany Carl Diem has gradually become consigned to oblivion, and that correspondingly in recent decades, any assessment of his work has increasingly become limited to his political ideas, actions, and work, should not be deemed an obstacle to his achievements for Bulgarian sport being judged on merit.

For the above reasons, there have been no satisfactory or comprehensive research work on Carl Diem here in the country so far. There are still much material awaiting discovery and analysis. Such a work of academic analysis will not be limited to examining the "Organizational Plan" relevant to the training of Bulgarian sport teachers and the organization of sport in the country, but will also take into account the social and political circumstances and conditions, the general spirit of time and the reception of his proposals.

Although, in principle, the "Diem Debate" may seem appropriate for historiography, this debate cannot and should not be imposed on the Bulgarian context. First of all, the most extensive possible study of his work and his contribution to sport in Bulgaria will have to be carried out.

It is a fact that his "Organizational Plan" 
marks the beginning of the establishment of the first (and only) Bulgarian Sports University, which in 2022 will celebrate its eightieth anniversary. This seems like the right time for the contribution of the German sport to be properly honored.

\section{REFERENCES}

Bardareva, R. (2002). 60 godini NSA, Vasil Levski’. Sofia (In Bulgarian)

Becker, F. ( $\left.{ }^{3} 2019\right)$. Den Sport gestalten Carl Diems Leben (1882-1962), Duisburg

Benz, W. (2011). Erinnerungspolitik oder kritische Forschung? Der Streit um Carl Diem - Schwerpunktthema. Zeitschrift für Geschichtswissenschaft, 59th year, issue 3

Carl-Diem-Institut (Ed.) (1967). Carl Diem: Der Olympische Gedanke - Reden und Aufsätze, Schorndorf

COMDOS (2014). Darzhavna sigurnost i sportat, Iz arhivite na DS, $\mathrm{N}^{\circ} 19$, part 2 (in Bulgarian) // КРДОПБГДСРСБНА „Държавна сигурност и спортът“, Из архивите на ДС, $\mathrm{N}^{\circ} 19$, част II. Available at: https://www.comdos.bg/Нашите_издания/ds-i-sportat , see there: CD-19-SS-SPORT2.pdf

CuLDA (n.y.). Gesamtverzeichnis Tagebücher Carl Diem (Archive), Köln

CuLDA(Ed.) (2009). Carl Diem - Tagebücher 24.06.1882 - 15.09.1962, 3 volumes, Berlin

DokZentrum ansTageslicht.de (2004, aktual. 2015). Sportidol Carl DIEM. Wie Würzburg sich der Aufarbeitung stellt. Available at: https:// www.anstageslicht.de/themen/rechtsradikalismus/aufarbeitung-sportidol-carl-diem/

European Parliament (2012). Decision P7_TA (2012)0025 Die europäische Dimension des Sports. In: Entschließung des Europäischen Parlaments vom 2. Februar 2012 zu der europäischen Dimension des Sports
$(2011 / 2087(I N I))$. Available at https://www.europarl.europa.eu/doceo/document/TA-7-20120025_DE.pdf?redirect

Hoppe, H. J. (1979). Bulgarien - Hitlers eigenwilliger Verbündeter, Stuttgart

Hristova, D. (2012). Bulgaria li dava ideyata za olimpiyskata shtafeta? Sega // Ceza, iss. 4457(177),02.08.2012. available at http://old.segabg.com/article.php?sid=2012080200040001201 (in Bulgarian)

Jungbauer, A. (2004). Die Auseinandersetzung um „Sportvater“ Carl Diem - am Beispiel seiner Geburtsstadt Würzburg, die nun ihre größte Veranstaltungshalle umbenennt. SportZeiten - Sport in Geschichte, Kultur und Gesellschaft, iss. 1, pp. 93-101. Available also at: https://www.anstageslicht.de/themen/rechtsradikalismus/aufarbeitung-sportidol-carl-diem/ueberblick-carl-diem/

Jungbauer, A. (2015). So begann die Berichterstattung um Carl Diem. Available at: https:// www.anstageslicht.de/themen/rechtsradikalismus/aufarbeitung-sportidol-carl-diem/making-of-oeffentliche-diskussion-um-carl-diem/

Kapralos, S. (2019). Opening speech International science conference "Second European Games - 2019”, National Olympic Academy Belarus - 2019. Minsk. Records by Mitev. L., NSA Sofia

Krüger, M (2009). Carl Diem: Friede zwischen Turnen und Sport. In: Krüger, M. (Ed.) (2009) Der deutsche Sport auf dem Weg in die Moderne: Car Diem und seine Zeit. Münster, pp.153-172

Krüger, M. (Ed.) (2012). Erinnerungskultur im Sport: Vom kritischen Umgang mit Carl Diem, Sepp Herberger und anderen Größen des deutschen Sports. Münster

Krüger, M. (2010). Leben und Werk Carl Diems. Ein Forschungs- und Projektbericht. 
Sportwissenschaft, 40(4), pp. 268-284

Laude, A., Bausch, W. (2000). Der Sportführer. Die Legende um Carl Diem. Göttingen

Lehmann, St. (2008). Der vergessene Vater des Fackellaufs. Available at: https://www.spiegel.de/geschichte/olympia-1936-a-947704.html

Lennartz, K. (2000). Begegnungen: Carl Diem und Pierre de Coubertin, Stadion - Internationale Zeitschrift für Geschichte des Sports, iss.26 (2), pp. 193-244

Lohde, E. (2013). Eine Analyse der neuesten Diem-Debatte (Bachelor-thesis), München

Mentel, Ch. (2012). Mit den auftraggebenden Institutionen gab es ein großes Problem (Interview mit Frank Becker zu seiner Biographie Carl Diems, 01.12.2012). Available at: https://zeitgeschichte-online.de/interview/mit-den-auftraggebenden-institutionen-gab-es-ein-grosses-problem

Mitev, L. (1996a). Menschliche Werte und Bewegungskultur in der kommunistischen Gesellschaft Bulgariens 1944-1989. In: André Gounot et al. (Ed.) (1996) Welt der Spiele. Politische, soziale und pädagogische Aspekte. Proceedings of the 2nd ISHPES-Congress 'Games of the World - the World of Games'. Berlin
Mitev, L. (1996b). Krayat na sayuza na balgarskite gimnasticheski druzhestva 'Yunak' 100 godini gimnastika v Bulgaria. pp.26-34, Sofia (In Bulgarian)

Mitev, L. (2002). Izgrazhdaneto na totalitaren model na telesnata kultura - Bulgarskiyat model 1937-1949. (Diss.). Sofia (In Bulgarian)

Mitev, L(2014). Olimpiyskata slava na Bulgaria - The Olympic Glory of Bulgaria. Sofia. (In Bulgarian and English)

Petrova, N. (1983). Uchilishtnoto fizichesko vazpitanie prez kapitalazma (1878-1944). (Diss.) Sofia (In Bulgarian)

Stein, O. (2011). Die deutsch-bulgarischen Beziehungen seit 1878. Zeitschrift für Balkanologie, iss. 47(2), p. 218 ff. Available at: http://www.zeitschrift-fuer-balkanologie.de/ index.php/zfb/article/view/273

Uchilishten pregled (1938). Organizatsionen otdel. p. 855 ff. (In Bulgarian)

Vitanova, E. (2016). Obrazovatelnata politika na NSA ,Vasil Levski‘ 1942-2012 (Diss.), Sofia (In Bulgarian)

Zlatarski, V. (2020). Rayhat i tsarstvoto - Germanskoto prisastvie v Bulgaria (19331940), Sofia (In Bulgarian)

\section{Corresponding author:}

Jörg Schenk

Department „History and Management of sport” National Sports Academy „Vassil Levski” 21, Acad. Stefan Mladenov Str. Sofia 1700, Bulgaria E-mail: levski@web.de 